\title{
Estimate of throughput of bridge transitions and pipe passages built on minor rivers of piedmont areas of Krasnodar Territory- Russia
}

\author{
Fedor Bryukhan ${ }^{1, *}$, Aleksey Vinogradov ${ }^{2}$ \\ ${ }^{1}$ Moscow State University of Civil Engineering, Yaroslavskoe shosse, 26, Moscow, 129337, Russia \\ ${ }^{2}$ Saint Petersburg State Forest Technical University, Institutskiy per., 5, Saint-Petersburg, 194021, Russia
}

\begin{abstract}
Stability and accident-free operation of engineering road structures including bridge transitions and pipe passages built on mountain rivers mostly depends on a stream regime and lack of obstructions for water flow. Such structures pose a prominent potential hazard being built in piedmont areas of Caucasus Mountains characterized by flash floods and blockage of structures by floating debris, mudflow deposits and wastes of construction. This notwithstanding, the threats caused by these phenomena are poorly studied. The purpose of this study is in estimation of throughput of bridge transitions and pipe passages built on minor rivers of piedmont areas and analysis of hazards caused by floods and obstructions to water flow. The results of calculation of capacities of existing road structures are provided herein. A qualitative assessment of potential emergencies in case of severe flood is also given. A major hazard of possible blockage of waterways that can cause emergency even in regular flood conditions is noted.
\end{abstract}

\section{Introduction}

In the context of intensive building activities including engineering and construction of roads on the Black Sea Coast of Krasnodar Territory, the man-made hazards of the projects under construction is particularly topical [1]. The floods of mountain rivers and blockage of waterways due to floating debris, mudflow deposits and wastes of construction is one of the sources of both natural and man-made hazards that can cause emergencies [2-4]. An example of the occurrence of the floating debris is shown in Fig. 1.

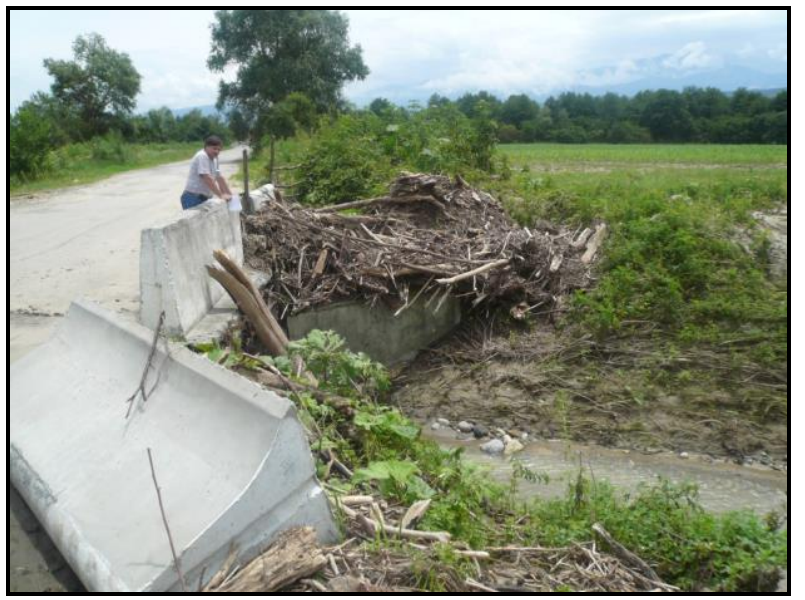

Fig. 1. Floating debris near the bridge transition over watercourse \#1 after a flash flood.
This notwithstanding, the respective issues of hydrologic support to building and operating of road structures are poorly studied. Therefore, the purpose of this study is to estimate the throughput of engineering road structures built on minor rivers of piedmont areas and analysis of hazards caused by floods and obstructions to water flow.

\section{Data and methodology}

The low density of gauging stations grid is the feature of the minor rivers of Northern Caucasia. Thus, a maximum runoff of rainfall flood is calculated using the Maximum Rainfall Intensity Method recommended by [5].

The maximum daily precipitation depth of 1 percent exceedance based on long-term weather records for a studied area over a period of 1940-2010 published by the Northern Caucasus Service for Hydrometeorology and Environmental Monitoring was used in calculation.

\section{Results and discussion}

For purposes of the Preliminary Hazard Analysis (PHA), only those hazards to a number of culverts on piedmont rivers that can be caused by dangerous hydrologic phenomena are reviewed. As soon as the accident mechanisms of hydraulic structures and spring-loaded pipe passages outbreaks are identical, the terms given in [6] will be used in accident risk analysis for a certain bridge transition. 
The waterways of hydraulic structures are reviewed below as the only elements that can be exposed to potential hazard. The results of PHA are given in the Table 1.

The What-If Risk Analysis Technique [6, 7], that became widely used in various theoretical and experimental areas was used at the stage of the hazard identification. The results of the hazards identification are given in the Table 2 .

Let us focus on some specific targets. The first conditions to be observed are on road passages through watercourse on the road section Novorossiysk-Sochi between Sequa River and Malaya Plyakho River near Novomikhailovsky Village of Tuapse District.

The watercourse of the area under review belongs to a water-resource region of the Western Transcaucasia [5]. Its water regime depends on average elevation of drainage basin and level difference. The slope exposure has a great impact on distribution of precipitation, and therefore regime of run-off. The major part of reception basin area is forested.

Table 1. Results of the PHA in connection with waterways.

\begin{tabular}{|l|l|l|}
\hline $\begin{array}{c}\text { Undesirable } \\
\text { phenomenon, } \\
\text { process or event } \\
\text { that can trigger } \\
\text { an accident }\end{array}$ & $\begin{array}{c}\text { Expected impact } \\
\text { for people, } \\
\text { property and } \\
\text { environment }\end{array}$ & $\begin{array}{c}\text { Preliminary } \\
\text { estimation of } \\
\text { scenario } \\
\text { probability }\end{array}$ \\
\hline $\begin{array}{l}\text { Flood and } \\
\text { blockage of } \\
\text { waterway } \\
\text { sections by } \\
\text { floating debris }\end{array}$ & $\begin{array}{l}\text { Outbreak of } \\
\text { hanging dam or } \\
\text { its failure with an } \\
\text { outburst of } \\
\text { breaking wave } \\
\text { downstream }\end{array}$ & $\begin{array}{l}\text { Highly probable } \\
\text { event due to } \\
\text { narrow waterway } \\
\text { sections, frequent } \\
\text { flood events and } \\
\text { presence of } \\
\text { floating debris } \\
\text { near river channel }\end{array}$ \\
\hline $\begin{array}{l}\text { Mudflow with } \\
\text { consequent } \\
\text { ablation of } \\
\text { supports, } \\
\text { reduction of } \\
\text { cross-sectional } \\
\text { area of waterway } \\
\text { sections or } \\
\text { blockage of water } \\
\text { inlets }\end{array}$ & $\begin{array}{l}\text { Construction } \\
\text { failure and } \\
\text { outbreak of } \\
\text { hanging dam with } \\
\text { an outburst of } \\
\text { breaking wave } \\
\text { downstream }\end{array}$ & $\begin{array}{l}\text { Improbable due } \\
\text { to rarity }\end{array}$ \\
\hline
\end{tabular}

Table 2. Results of What-If technique use.

\begin{tabular}{|c|c|c|c|}
\hline $\begin{array}{l}\text { Name of } \\
\text { element }\end{array}$ & $\begin{array}{l}\text { Damage } \\
\text { source }\end{array}$ & $\begin{array}{l}\text { Type and } \\
\text { scale of } \\
\text { damage }\end{array}$ & $\begin{array}{l}\text { Effects to people, } \\
\text { property and } \\
\text { environment }\end{array}$ \\
\hline $\begin{array}{l}\text { Waterway of } \\
\text { bridge } \\
\text { transition or } \\
\text { pipe passage }\end{array}$ & $\begin{array}{l}\text { Blockage of } \\
\text { waterways } \\
\text { and sections }\end{array}$ & $\begin{array}{l}\text { Raising of } \\
\text { water level, } \\
\text { structural } \\
\text { instability } \\
\text { and failure }\end{array}$ & $\begin{array}{l}\text { Outburst of } \\
\text { breaking wave } \\
\text { downstream, } \\
\text { formation of } \\
\text { breaking mudflow, } \\
\text { failure of a part of } \\
\text { bridgework, } \\
\text { failure the flat } \\
\text { accommodation } \\
\text { and infrastructure } \\
\text { facilities, loss of } \\
\text { life and substantial } \\
\text { damage to } \\
\text { environment }\end{array}$ \\
\hline
\end{tabular}

The observed data available at the Northern Caucasus Service for Hydrometeorology and Environmental Monitoring was collected and classified in order to analyze a study degree of the adjacent areas. The best known areas are essentially represented for rivers characterized by $200-500 \mathrm{~km}^{2}$ drainage area and located to the north of the area under study. The rivers of smaller drainage areas are whether not observed at all, or covered by short-term observations. The analysis of the records of peak discharge over many years revealed the peak discharge of the rivers on the area under study is ten times greater than average peak discharge or more. In these conditions, unit discharge increases when a drainage area decreases.

According to the geographical demarcation provided in [8], the rivers in the area under review are classified as the zone of summer floods. However, as soon as each stream located in the area under study is not large and has a drainage basin at the feet of hillside (up to $550 \mathrm{~m}$ by Baltic Height System), there is no glacial and sufficient snow feed for it. Thus, maximum runoff of every watercourse is formed only by rainfall floods that are possible in any season. This enables formation of a very high rainfall flood with heavy precipitation covering an entire drainage area and physical and hydrographical properties of a channel networks provides for shortest basin lag. Drainage basins of these rivers can form the streams characterized by up to 20 $\mathrm{m}^{3} /\left(\mathrm{s} \times \mathrm{km}^{2}\right)$ of unit discharge in case of heavy precipitation.

As previously stated, a formula of Maximum Rainfall Intensity was used in order to calculate a peak discharge of rainfall flood for the drainage basins under study. The comparative results of peak discharge for $1 \%$ annual exceedance probability (i.e. maximum calculated discharge with occurrence probability of 1 in 100 years [5]) and capacity of bridge transitions and pipe passages in discharge conditions are given in the Table 3.

Based on calculation and passages observation results it was discovered that most of them are not capable to endure discharging the flood of 1 percent exceedance as confirmed by wash-away of bridge transitions and pipe passages as a result of foods in 2002, 2009 and 2010. If it is remembered that waterways are blocked by stems and branches of trees, as well as construction wastes, then it can be said that none of the structure under study is capable to endure discharging a considerable flooding. Examples of the destructive impact of the floating debris are shown in Fig.s 2 and 3.

The event of a chain of hanging dams resulted from the blockage of culverts and their further sequential outbreaks can cause disastrous consequences. For example, the bridge transition on watercourse \# 9 (see Fig. 3) at a five-time margin of its throughput was completely blocked during a common rain shower. It caused a breakthrough of accumulated flood waters onto the road. It is seen that even at such throughput margin accident-free operation of the bridge cannot be ensured when the flow of floating debris is high. 
Table 3. Comparative results of peak discharge for $1 \%$ annual exceedance probability and throughput of bridge transitions and pipe passages in discharge conditions.

\begin{tabular}{|l|c|c|c|c|}
\hline $\begin{array}{c}\text { Water- } \\
\text { course* }\end{array}$ & $\begin{array}{c}\text { Drain- } \\
\text { age } \\
\text { area, } \\
\mathrm{km}^{2}\end{array}$ & $\begin{array}{c}\text { Peak } \\
\text { discharge } \\
\text { for 1\% } \\
\text { annual } \\
\text { exceedance } \\
\text { probability, } \\
\mathrm{m}^{3} / \mathrm{s}\end{array}$ & $\begin{array}{c}\text { Water- } \\
\text { way } \\
\text { section } \\
\text { area, } \\
\mathrm{m}^{2}\end{array}$ & $\begin{array}{c}\text { Throughput } \\
\text { for dis- } \\
\text { charge } \\
\text { conditions, } \\
\mathrm{m}^{3} / \mathrm{s}\end{array}$ \\
\hline$\# 1$ & 1.5 & 30 & 3.5 & 12 \\
\hline$\# 2 * *$ & 15 & 225 & 72 & 235 \\
\hline$\# 3$ & 0.18 & 5.4 & 0.5 & 0.8 \\
\hline$\# 4$ & 0.1 & 3.0 & 0.8 & 1.9 \\
\hline$\# 5$ & 0.13 & 3.9 & 1.8 & 4.9 \\
\hline$\# 6$ & 0.03 & 0.9 & 3.2 & 21 \\
\hline$\# 7$ & 0.46 & 9.2 & 1.8 & 6.4 \\
\hline$\# 8 * * *$ & 8.2 & 164 & 14 & 98 \\
\hline$\# 9$ & 3.4 & 1.51 & 3.2 & 7.7 \\
\hline$\# 10^{* * * *}$ & 762 & 764 & 152 & 780 \\
\hline
\end{tabular}

* Watercourses are numbered consecutively - starting from unnamed watercourse \# 1 and to Mzymta River (\# 10) in the south.

** Malaya Plyakho River.

*** Sequa River.

**** Mzymta River

The bridge transition having a waterway sized at $3.8 \times 3.8 \mathrm{~m}$ and built on Sequa River is exposed to the highest risk. If water rises at a waterway to $4 \mathrm{~m}$ or more, it flows in a pressurized regime calculated approximately. When water level rises up to $8 \mathrm{~m}$ (with water outbreak onto the road), the maximum discharge in the culvert not blocked by floating debris is $98 \mathrm{~m}^{3} / \mathrm{s}$, and that is significantly lower than the peak discharge for $1 \%$ annual exceedance probability estimated as 164 $\mathrm{m}^{3} / \mathrm{s}$. At that, average peak discharge is $34 \mathrm{~m}^{3} / \mathrm{s}$. Once in several years the area upstream of the bridge is flooded, and, due to abundant floating debris, the road structure is damaged and outbreaks of flood water occur.

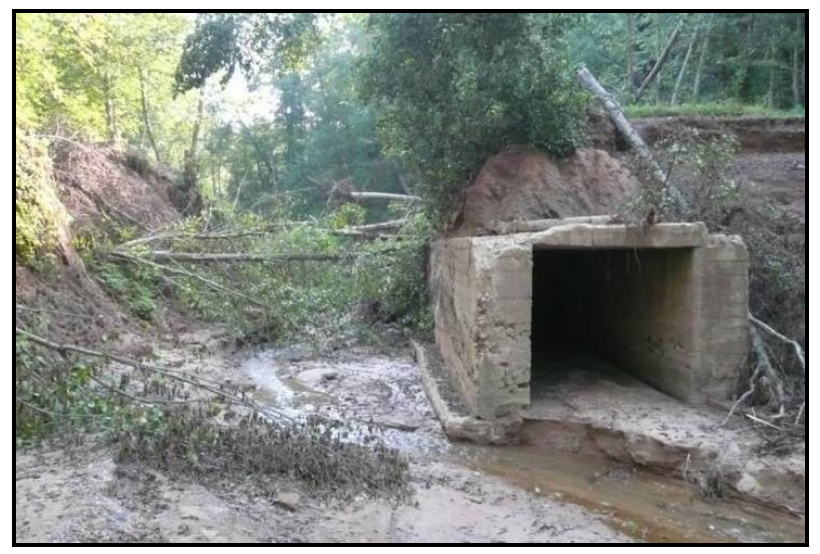

Fig. 2. The destructive impact of floating debris at bridge transition on watercourse \# 5 .

The next target under review is a newly-built bridgework passing Mzymta River, a major watercourse of Sochi Resort. The in-stream support of the bridge (pier) is located in over-water length near Kepsha
Settlement close to Krasnaya Skala. The width of a stream valley in its narrowest point where the pier of the cable bridge is erected is up to $60 \mathrm{~m}$. The pier narrows the width of waterways down to $20 \mathrm{~m}$. Although the size of waterway is enough to maintain a regular flood, the probability of its blockage is very high in the event of a great number of floating debris. The approximate volume of water that can be accumulated in the water head of the bridgework under review can reach about 3 MCM. The height of a breaking wave in the first travel kilometer reaches $20 \mathrm{~m}$ with a breakthrough rate of discharge at about $10^{4} \mathrm{~m}^{3} / \mathrm{s}$ [3]. There is a high probability of mudflow in the event of outbreak due to a great volume of debris, detritus and construction waste in a river channel. The volume of such flow can reach 50 MCM with momentary discharge of up to $5 \times 10^{4} \mathrm{~m}^{3} / \mathrm{s}$. Every 5 or 7 years an emergency can be expected for this structure at a calculated discharge of $199 \mathrm{~m}^{3} / \mathrm{s}$.

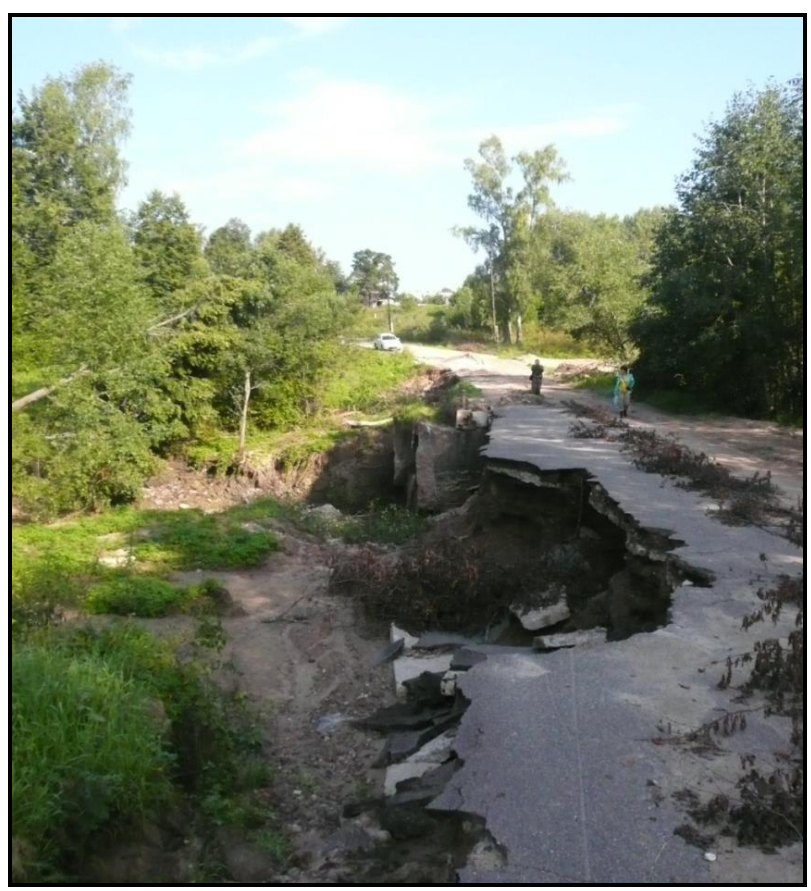

Fig. 3. Consequences of a flash flood at bridge transition on watercourse \# 9 .

According to the results of PHA, the natural and man-caused impact can become the external causes of accidents and emergencies happened to piers of the bridgework under review built on the road near Kepsha Settlement as follows:

- earthquake followed by landslide near the bridge piers;

- flooding followed by debris floating;

- and mudflow.

The high probability of described above scenarios is supported by emergencies repeatedly happened in North Caucasian Federal District (e.g. Krymsk, 2012).

\section{Conclusions}

- The minor rivers of Northern Caucasus Region are characterized by high rainwater floods. The drainage 
basins of these rivers adjacent to Black Sea Coast are capable to develop the streams characterized by a runoff rate of $20 \mathrm{~m}^{3} /\left(\mathrm{s} \times \mathrm{km}^{2}\right)$ in the event of heavy precipitation (250 $\mathrm{mm}$ per day or more). When this happens, the capacity of larger part of road structures built in recent decades in Northern Caucasia to discharge rare floods raises reasonable doubts.

- Almost every watercourse in this region is highly contracted in places of bridge transitions and pipe passages. In the event of flash flooding bridge waterways and pipe passages would be blocked by floating debris and sediments. The area would be flooded with a high risk of following of outbreak of flood water. The event of a chain of hanging dams resulted from the blockage of culverts and their further sequential outbreaks can cause disastrous consequences.

- The discharge of breaking wave containing a large volume of carrying rock, floating debris and waste to a sea shore can cause a failure of accommodation and infrastructure facilities, blocking of traffic network, loss of life and severe environmental damage.

\section{References}

1. A.A. Goncharov, Sistemy Bezopasnosti, No 1, 365368 (2014) - in Russian.

2. M. Bollschweiler, M. Stoffel, Prog. Phys. Geog., 34 (2010).

3. A.Yu. Vinogradov, Bull. of the Moscow State Regional University, ser. "Natural Sciences", No 4, 52-56 (2014) - in Russian.

4. M. Stoffel, B. Wyżga, R.A. Marston, Geomorphology, 272 (2016).

5. SP 33-101-2003. (Gosstroy of Russia, Moscow, 2004) - in Russian.

6. Hydraulic structures accidents risk assessment guidelines (All-Russian Scientific Research Institute of Hydraulic Engineering, St. Petersburg, 2005) - in Russian.

7. A.J. Card, J.R. Ward, P.J. Clarkson, J. Healthc. Risk Manag., 31 (2012).

8. Atlas of designed hydrological maps and graphical charts (Gidrometeoizdat Publishing House, Leningrad, 1986) - in Russian. 